\title{
ESTIMATING BASAL ENERGY EXPENDITURE IN LIVER TRANSPLANT RECIPIENTS: THE VALUE OF THE HARRIS- BENEDICT EQUATION
}

\author{
Importância da Equação de Harris-Benedict na estimativa do metabolismo basal em pacientes transplantados de fígado
}

\author{
Andressa S. PINTO ${ }^{1}$, Marcio F. CHEDID ${ }^{1,2}{ }^{2}$, Léa T. GUERRA ${ }^{3}$, Mario R. ÁLVARES-DA-SILVA ${ }^{4}$, \\ Alexandre de ARAÚJO', Luciano S. GUIMARÃES ${ }^{5}$, lan LEIPNITZ², Aljamir D. CHEDID², \\ Cleber R. P. KRUEL ${ }^{1,2}$ Tomaz J. M. GREZZANA-FILHO', Cleber D. P. KRUEL ${ }^{1,2}$
}

From the ${ }^{1}$ Programa de Pós-Graduação em Medicina: Ciências Cirúrgicas; ${ }^{2}$ Serviço de Cirurgia Digestiva e Transplantes de Fígado e Pâncreas; ${ }^{3}$ Senviço de Nutrição; ${ }^{4}$ Senviço de Gastroenterologia e Hepatologia; ${ }^{5}$ Senviço de Bioestatística, Grupo de Pesquisa e PósGraduação, Hospital de Clinicas de Porto Alegre, Universidade Federal do Rio Grande do Sul, Porto Alegre, RS ('Postgraduate Program in Surgical Sciences; ${ }^{2}$ Division of Gastrointestinal Surgery and Liver and Pancreas Transplantation; ${ }^{3}$ Unit of Dietary Therapy; ${ }^{4}$ Division of Gastroenterology and Hepatology; ${ }^{5}$ Division of Medical Statistics, Hospital de Clínicas de Porto Alegre, Federal University of Rio Grande do Sul), Porto Alegre, RS, Brazil

HEADINGS - Liver transplantation. Basal Energy Expenditure. Indirect Calorimetry. Bioelectrical Impedance. Harris-Benedict equation. Mifflin-St. Jeor equation.

\section{Correspondence: \\ Marcio F. Chedid \\ E-mail: marciochedid@hotmail.com}

Financial source: FIPE (Fundo de Incentivo à Pesquisa), Grupo de Pesquisa e PósGraduação (GPPG), Hospital de Clínicas de Porto Alegre

Conflicts of interest: none

Received for publication: 08/12/2015 Accepted for publication: 14/04/2016

DESCRITORES - Transplante de fígado Metabolismo basal. Calorimetria indireta. Bioimpedância. Equação de HarrisBenedict. Equação de Mifflin-St. Jeor.
ABSTRACT - Background: Reliable measurement of basal energy expenditure (BEE) in liver transplant (LT) recipients is necessary for adapting energy requirements, improving nutritional status and preventing weight gain. Indirect calorimetry (IC) is the gold standard for measuring BEE. However, BEE may be estimated through alternative methods, including electrical bioimpedance (BI), Harris-Benedict Equation (HBE), and Mifflin-St. Jeor Equation (MSJ) that carry easier applicability and lower cost. Aim: To determine which of the three alternative methods for BEE estimation (HBE, BI and MSJ) would provide most reliable BEE estimation in LT recipients. Methods: Prospective cross-sectional study including dyslipidemic LT recipients in follow-up at a 735-bed tertiary referral university hospital. Comparisons of BEE measured through IC to BEE estimated through each of the three alternative methods ( $\mathrm{HBE}, \mathrm{BI}$ and MSJ) were performed using Bland-Altman method and Wilcoxon Rank Sum test. Results: Fortyfive patients were included, aged $58 \pm 10$ years. BEE measured using IC was $1664 \pm 319 \mathrm{kcal}$ for males, and $1409 \pm 221 \mathrm{kcal}$ for females. Average difference between BEE measured by IC $(1534 \pm 300 \mathrm{kcal})$ and $\mathrm{BI}(1584 \pm 377 \mathrm{kcal})$ was $+50 \mathrm{kcal}(p=0.0384)$. Average difference between the BEE measured using IC ( $1534 \pm 300 \mathrm{kcal})$ and MSJ $(1479.6 \pm 375 \mathrm{kcal})$ was $-55 \mathrm{kcal}(p=0.16)$. Average difference between BEE values measured by IC $(1534 \pm 300 \mathrm{kcal})$ and HBE $(1521 \pm 283$ $\mathrm{kcal})$ was $-13 \mathrm{kcal}(p=0.326)$. Difference between BEE estimated through IC and HBE was less than $100 \mathrm{kcal}$ for 39 of all 43patients. Conclusions: Among the three alternative methods, HBE was the most reliable for estimating BEE in LT recipients.
RESUMO - Racional: Estimativa confiável do metabolismo basal em pacientes transplantados de fígado é necessária para adaptar os requerimentos energéticos, melhorar o estado nutricional e prevenir ganho de peso. Calorimetria indireta $(\mathrm{Cl})$ é o padrão-ouro para a medição do metabolismo basal. No entanto, ele pode ser estimado utilizando-se métodos alternativos, incluindo a bioimpedância (BI), a Equação de Harris-Benedict (EHB), e também a Equação de Mifflin-St. Jeor (MSJ). Esses métodos alternativos possuem aplicabilidade mais fácil e custo inferior quando comparados à $\mathrm{Cl}$. Objetivo: Determinar qual dos três métodos alternativos para a estimativa do metabolismo basal (EHB, Bl e MSJ) seria o mais confiável em pacientes transplantados de fígado. Métodos: Foi realizado estudo transversal prospectivo incluindo pacientes transplantados de fígado com dislipidemia, em acompanhamento ambulatorial. Comparações dos valores calculados de metabolismo basal via $\mathrm{Cl}$ aos valores estimados por cada um dos três métodos alternativos (EHB, BI e MSJ) foram realizadas utilizando o de Bland-Altman e o teste de Wilcoxon-Mann-Whitney. Resultados: Quarenta e cinco pacientes foram incluídos com idade $58 \pm 10$ anos. O metabolismo basal medido via $\mathrm{Cl}$ foi $1664 \pm 319$ kcal para pacientes do gênero masculino, e 1409 \pm 221 kcal para o feminino. A diferença média entre a taxa de metabolismo basal aferida por $\mathrm{Cl}(1534 \pm 300 \mathrm{kcal})$ e estimada por BI $(1584 \pm 377 \mathrm{kcal})$ foi $+50 \mathrm{kcal}(\mathrm{p}=0.0384)$. A diferença média entre a taxa de metabolismo basal aferida via $\mathrm{Cl}(1534 \pm 300$ $\mathrm{kcal}$ ) e estimada por MSJ ( $1479.6 \pm 375 \mathrm{kcal})$ foi $-55 \mathrm{kcal}(p=0.16)$. A diferença média entre os valores de taxa de metabolismo basal medidos via $\mathrm{Cl}(1534 \pm 300 \mathrm{kcal})$ e estimados por EHB $(1521 \pm 283 \mathrm{kcal})$ foi $-13 \mathrm{kcal}(\mathrm{p}=0.326)$. Além disso, a diferença entre a taxa de metabolismo basal estimada via $\mathrm{Cl}$ e a aferida por EHB foi menor que $100 \mathrm{kcal}$ para 39 de todos os 43 pacientes avaliados. Conclusões: A EHB foi o mais confiável dos três métodos de estimativa da taxa de metabolismo basal em pacientes transplantados de fígado em acompanhamento ambulatorial.

INTRODUCTION

(cc) BY This is an open-acces article distributed under the terms of the Creative Commons Attribution License.
Ithough hypolipidemia may be a common finding in cirrhotic patients ${ }^{3}$, there is a rising prevalence of obesity and metabolic syndrome after liver transplantation ${ }^{1,11}$. Accurate estimation of the basal energy expenditure (BEE), in liver transplant (LT) recipients is necessary to guide improvements on nutritional status and prevent weight gain².

Indirect calorimetry (IC) is considered as the gold standard method for measuring BEE. However, it has technical limitations that include the need for well trained personnel and an elevated cost ${ }^{2}$. There are other methods for estimating the BEE that are easier 
to apply and less costly than IC. Among alternative methods for estimating the BEE - also known as Basal Metabolic Rate (BMR) - stand Bioelectrical Impedance (BI), the Harris-Benedict equation (HBE) and Mifflin-St. Jeor equation (MSJ).

The aim of this study was to measure BEE in $L T$ recipients through IC and compare IC-calculated BEE values to those estimated through three alternative methods $\mathrm{BI}, \mathrm{HBE}$ and Mifflin-St. Jeor equation (MSJ).

\section{METHODS}

This is a prospective cross-sectional study that includes all adult LT recipients on dietary outpatient follow-up for dyslipidemia at our service. All patients were selected from a cohort of 199 adult who received a whole-graft LT from a deceased donor at our institution between 2002 and 2014. This study was approved by local IRB and all patients consented before being enrolled.

Inclusion criteria were age $>18$ years-old, dyslipidemia and at least two months of post-transplant follow-up. Patients who were on drug treatments for dyslipidemia, patients who were using alcohol, handicapped and those who did not consent, were excluded.

All patients underwent evaluation by a dietician before being enrolled. Body weight, height, body mass index (BMI) and waist were measured. BEE was calculated using $\mathrm{IC}$, and also estimated through $\mathrm{BI}, \mathrm{HBE}$ and MifflinSt. Jeor Equation (MSJ) by a single researcher (Pinto, A. S.).

\section{Indirect calorimetry (IC)}

IC is a noninvasive method for calculating BEE by utilizing the volume of expired oxygen and production of carbon dyoxide obtained through analyzing the air expired by the lungs ${ }^{3}$. BEE was estimated in a thermoneutral environment (Metabolic Gas Analyzer VO 2000, Software Aerograph Breeze, Medical Graphics - Cardiorespiratory Diagnostic Systems), after the patient was fasting for at least $6 \mathrm{~h}$. Patients rested for at least $30 \mathrm{~min}$ before data were collected. The system was adjusted before each measurement. Oxygen consumption and $\mathrm{CO} 2$ production were measured after the patient stood in supine position for at least $25 \mathrm{~min}$.

\section{Bioelectrical impedance (BI)}

Patients were instructed to fast for at least $8 \mathrm{~h}$ before the exam, and not to practice physical activities during $24 \mathrm{~h}$ preceding the exam. BMI analyzer (model Bodystat ${ }^{\circledR} 1500$ ) utilizes four small probes, being one applied on right hand and another on right wrist, a third on right ankle and the last one on right foot. BI measures were performed on the right side of the body. Patient was positioned on supine position, with both legs in contact and arms not touching the body ${ }^{12}$. Lean mass and fat mass were measured through BI.

\section{Harris-Benedict Equation (HBE)}

For estimating BEE through using the Harris-Benedict Equation ( $\mathrm{HBE}$ ) ( $\mathrm{kcal} / \mathrm{day})$ the following equation was utilized for male gender: $66.47+(13.75 x$ weight in $\mathrm{kg})+(5.003 \mathrm{x}$ height in $\mathrm{cm})-(6.775 \mathrm{x}$ age in years). For female gender, the following equation was utilized: $655.09+(9.563 \times$ weight in $\mathrm{kg})+(1.85 \mathrm{x}$ height in $\mathrm{cm})-(4.676 \mathrm{x} \text { age in years })^{4}$.

\section{Mifflin-St. Jeor Equation (MSJ)}

For estimating BEE through using the MSJ (kcal/day) the following equation was utilized for male gender: $10 x$ weight $(\mathrm{kg})+6.25 \mathrm{x}$ height $(\mathrm{cm})-5 \mathrm{x}$ age $(\mathrm{y})+5$. For female gender, the following equation was utilized: $10 \mathrm{x}$ weight $(\mathrm{kg})+6.25 \mathrm{x}$ height $(\mathrm{cm})-5 \mathrm{x}$ age $(\mathrm{y})-161^{14}$.

\section{Statistical analysis}

Categorical variable comparisons were performed utilizing Chi-Square test. Regarding the high cost involved with utilizing indirect calorimetry and patient visits, BEE measurements were performed only once. Numeric variables were compared utilizing T test and/or Mann-Whitney $U$ test as appropriate. Univariate analysis performed through simple linear regression analyzed association of demographic variables (percentage of lean mass, age and BMI), to BEE calculated through IC. "X" variable was each demographic variable, and BEE was the " $Y$ " variable. The association of gender (" $X$ " variable) and BEE ("Y" variable) was analyzed through oneway Wilcoxon Rank Sum Test. Variables exhibiting $p$ value $<0.1$ were selected for multivariate analysis using multiple linear regressions. Bland-Altman method was utilized for comparisons between the three alternative methods for estimating $B E E, B I, H B E$ and MSJ to the gold standard IC. JMP Statistical Discovery version 12 (SAS, Cary, NC, USA) and was utilized for statistical analyses. Excel for Windows (Redmond, Washington, US) was utilized for construction of Bland-Altman plots. $p$-values $<0.05$ were considered as statistically significant.

\section{RESULTS}

Forty-five patients in post-transplant outpatient followup (two months to 11 years post-transplant) were included in this study. These were 22 male and 23 female patients, mean age $58 \pm 10$ years (Tables 1 and 2 ).

TABLE 1 - Demographic and anthropometric characters for the whole study cohort $(n=45)$.

\begin{tabular}{|c|c|}
\hline Variable & Value (\%) \\
\hline \multicolumn{2}{|l|}{ Gender - n (\%) } \\
\hline Male & $22(48,88 \%)$ \\
\hline Female & $23(51,11 \%)$ \\
\hline Age (years) - Mean \pm Std. Dev. & $58 \pm 10$ \\
\hline BMI $\left(\mathrm{kg} / \mathrm{m}^{2}\right)-$ Mean \pm Std. Dev. & $27.83 \pm 5.38$ \\
\hline CW $(\mathrm{cm})-$ Mean \pm Std. Dev. & $94.3 \pm 13.80$ \\
\hline LM (\%) - Mean \pm Std. Dev. & $66.14 \pm 7.56$ \\
\hline FM (\%) - Mean \pm Std. Dev. & $33.81 \pm 7.53$ \\
\hline
\end{tabular}

TABLE 2 - Demographic and anthropometric characters stratified by gender

\begin{tabular}{ll} 
Male $(n=22)$ & Female $(n=23)$ \\
BMI $=27.92 \pm 5.43$ & $B M I=27.74 \pm 5.45$ \\
\hline Neck circumference $=99.75 \pm 13.5$ & Neck circumference $=89.1 \pm 12.2$ \\
\%Lean mass $=70.5 \pm 5.1$ & \% Lean mass $=61.9 \pm 7.2$ \\
\%Fat mass $=29.5 \pm 5.1$ & \% Fat mass $=38 \pm 7.2$
\end{tabular}

$\mathrm{BMI}=$ body mass index

Twenty five patients were aged less than 60 years-old, and 20 aged 60 or older. Patients younger than 60 years had a mean $\mathrm{BMI}$ of $28.6 \pm 5.9$, the mean BMI being $26.9 \pm 4.6$ for older than 60 years. All 45 patients had undergone LT more than six months prior to being evaluated in this study. Thirty-eight of the total 45 patients were evaluated after standing at least one year after LT.

Mean IC-calculated BEE was $1534 \pm 300$ (Figure 1). Mean BEE as estimated through IC was $1664 \pm 319 \mathrm{kcal}$ for male and $1409 \pm 221 \mathrm{kcal}$ for female patients $(p=0.004)$. For the entire cohort, percentage of mean lean mass was $66.14 \% \pm 7.6$. For the entire cohort, univariate analysis (simple linear regression) revealed age not to be associated to an increase or reduction in the BEE $(p=0.2)$. Percentage of lean mass was not associated to difference in the BEE $(p=0.78)$. An increase in the BMI was associated to an increase in the BEE $(p=0.0001)$. Multivariate 
analysis utilizing the two factors that were associated to an increase in the $\mathrm{BEE}$ (male gender and $\mathrm{BMI}$ ) revealed both male gender $(p=0.0001)$ and $B M I(p=0.0001)$ as independently associated to an increase in the BEE.

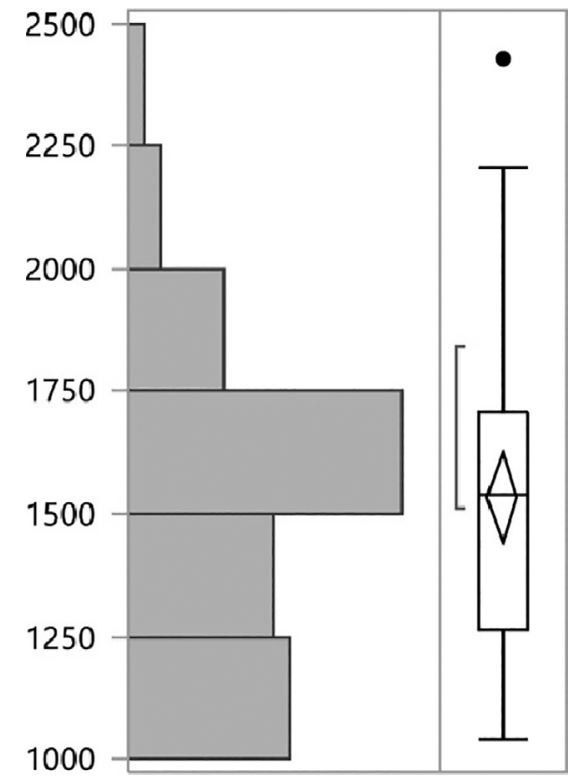

FIGURE 1 - BEE distribution for the whole sample using IC

Mean HBE-calculated BEE was $1521 \pm 283$ (Figure 2A). As estimated using the Bland-Altman method, bias of BEE measured through IC $(1534 \pm 300)$ and estimated through HBE was $-13 \mathrm{kcal}$. Upper confidence limit (UCL) was $163 \mathrm{kcal}$, and lower confidence limit (LCL) was $-190 \mathrm{kcal}$ (confidence interval $=353 \mathrm{kcal}$, Figure 2B). As estimated through Wilcoxon Rank Sum Test, the difference between BEE calculated through IC and estimated through HBE was not statistically significant $(p=0.326)$. This difference was higher than $10 \%$ for only two patients. Also, this difference was higher than $100 \mathrm{kcal}$ for only six out of 45 total patients.

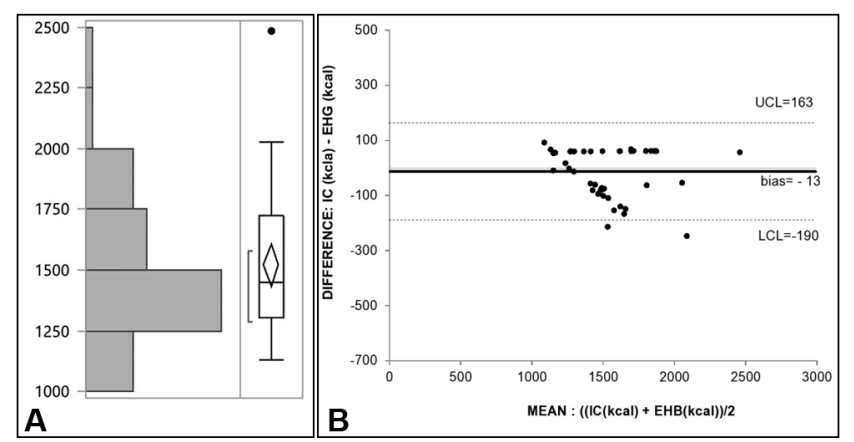

$\mathrm{UCL}=$ ppper confidence limit; $\mathrm{LCL}=$ lower confidence limit; * $\mathrm{p}$-values were calculated through Wilcoxon Rank Sum Test

FIGURE 2 - A) BEE distribution for the whole sample using $\mathrm{HBE}$; B) Bland-Altman Plot comparing BEE calculated through IC and $\mathrm{HBE}_{,}(\mathrm{p}=0.326)^{*}$

Mean BI-calculated BEE was $1584 \pm 377$ (Figure 3A). As estimated using the Bland-Altman method, bias of BEE measured through IC $(1534 \pm 300)$ and estimated through BI was +50 kcal. Upper confidence limit (UCL) was $357 \mathrm{kcal}$, and lower confidence limit (LCL) was $-257 \mathrm{kcal}$ (confidence interval $=500$ kcal) (Figure 3B). As estimated through Wilcoxon Rank Sum Test, the difference between BEE calculated through IC and estimated through $\mathrm{BI}$ was statistically significant $(p=0.038)$. This difference was higher than $10 \%$ for 13 of the total 45 patients. Also, this difference was higher than $100 \mathrm{kcal}$ for 19 out of 45 patients.

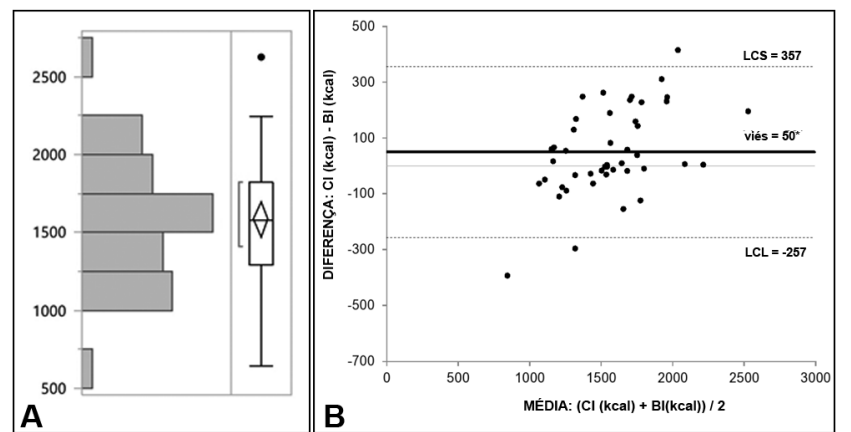

$\mathrm{UCL}=$ ppper confidence limit; $\mathrm{LCL}=$ lower confidence limit; * $\mathrm{p}$-values were calculated through Wilcoxon Rank Sum Test

FIGURE 3 - A) BEE distribution for the whole sample using $\mathrm{Bl}$; B) Bland-Altman Plot comparing BEE calculated through $I C$ and $B I(p=0.038)^{*}$

Mean MSJ-calculated BEE was 1480 \pm 375 (Figure 4A). As estimated using the Bland-Altman method, bias of BEE measured through IC (1534 \pm 300$)$ and estimated through MSJ was - 55 kcal. Upper confidence limit (UCL) was 446 kcal, and lower confidence limit (LCL) was $-555 \mathrm{kcal}$ (confidence interval=1,001 kcal) (Figure 4B). As estimated through Wilcoxon Rank Sum Test, the difference between BEE calculated through IC and estimated through $\mathrm{BI}$ was not statistically significant $(p=0.16)$. This difference was higher than $10 \%$ for 13 patients. Also, this difference was higher than $100 \mathrm{kcal}$ for 21 out of the total 45 patients.

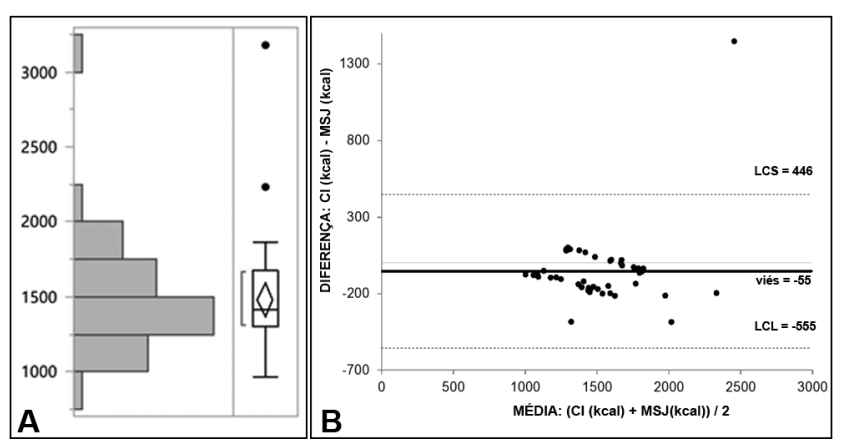

$\mathrm{UCL}=$ ppper confidence limit; $\mathrm{LCL}=$ lower confidence limit; ${ }^{*} \mathrm{p}$-values were calculated through Wilcoxon Rank Sum Test

FIGURE 4 - A) BEE distribution for the whole sample using MSJ; B) Bland-Altman Plot comparing BEE calculated through IC and MSJ $(p=0.16)^{*}$

\section{DISCUSSION}

A recent study revealed an overweight prevalence of $45 \%$ for LT recipients by the end of the first post-transplant year ${ }^{1}$. During the second this prevalence was $60 \%$, being as high as $70 \%$ on the third post-transplant year ${ }^{16,18}$. The present study revealed an overweight prevalence that is similar to previous studies $^{17}$ (55\% for patients aged less than 60 years and $30 \%$ for patients aged older than 60 years-old).

In the present study, mean BEE calculated through using IC was $1534 \mathrm{kcal}$. BEE was statistically higher for male patients than for females. As to age, an increased age was associated to a decreased $\mathrm{BEE}^{21}$. The only two independent predictors for an increased in the BEE estimated through IC were male gender and BMI. Thus, neither age nor percentage of lean mass were associated to an increased BEE. Richardson et al. followed 23 patients until they reached the $9^{\text {th }}$ post-transplant month, and observed that a lower BEE as calculated through IC was an important predictor for fat mass gain after liver transplant ${ }^{6}$.

Besides the gold standard IC, there are alternative methods for estimating BEE such as BI, HBE and MSJ. Clinical use of HBE 
has been debated ${ }^{5,8-9,13,15,19,22}$. A study analyzing healthy subjects aged $18-30$ years, using the HBE underestimated the BEE in $2.91 \%$ for female and $6.61 \%$ for male $(p<0.05)^{4}$. Two other studies, the first analyzing patients undergoing elective surgery and the other analyzing patients suffering from liver failure detected significant differences between energy consumption measured through IC and the one estimated through HBE. In one study, $\mathrm{HBE}$ underestimated the energetic needs by $25 \%{ }^{10}$. Another study from our institution detected HBE to overestimate BEE as compared to $\mathrm{IC}^{17}$.

This is the first study comparing BEE estimated through alternative methods ( $\mathrm{HBE}, \mathrm{BI}$ and $\mathrm{MSJ})$ to the one measured through IC in $L T$ recipients. In the present research, $\mathrm{HBE}$ underestimated BEE. However, the mean difference was small (13 kcal), not statistically significant, and with a much lower confidence interval as compared to the other two alternative methods ( $\mathrm{BI}$ and MSJ). This suggests that HBE is more reliable for determining BEE in LT recipients in outpatient follow-up than the other two alternative methods (BI and MSJ). Moreover, the difference of BEE calculated through IC and estimated through HBE was higher than $100 \mathrm{kcal}$ for only six out of 45 total patients, being higher than $10 \%$ for only two patients. Thus, in the present study sample, HBE proved as the most reliable alternative method for estimating $B E E$.

The limitations of this study pertain to its inclusion criteria (dyslipidemic liver recipients), which could have tended towards selecting the most obese of our LT recipients. However, considering that overweight prevalence was similar to that of $\mathrm{LT}$ recipient populations analyzed in prior studies, it is likely that the findings from this study can be generalized to the LT recipient pool ${ }^{1,16-17}$.

Weight control measures are warranted to control weight gain in LT recipients and prevent obesity in this patient population. Male LT recipients have a BEE that is statistically higher than female patients who have a similar BMI. For individuals of the same gender, an increased BMI is associated to an increased $B E E$. HBE seems to be a reliable method for estimating the $B E E$ in $L T$ recipients on outpatient follow-up. Whenever there is unavailability of IC, $\mathrm{HBE}$ rather than $\mathrm{BI}$ or MSJ should be the method of choice for estimating the BEE in $L T$ recipients.

\section{CONCLUSION}

Among the three alternative methods ( $\mathrm{HBE}, \mathrm{BI}$ and MSJ), $\mathrm{HBE}$ was the most reliable for estimating BEE in LT recipients.

\section{REFERENCES}

1. Anastácio LR, Lima AS, Correia MITD. Metabolic syndrome and its componentsafterlivertransplantation:Incidence, prevalence, riskfactors, and implications. Clin Nutr 2010; 29: 175-179.

2. BasileFilhoA,Martins MA,AntoniazziP,MarchiniJS.Acalorimetriaindireta no paciente em estado critico. Rev Bras Ter Intensiva 2003; 15: 29-33.
3. Boemeke L, Bassani L, Marroni CA, Gottschall CB. Lipid profile in cirrhotic patients and its relation to clinical outcome. Arq Bras Cir Dig. 2015; 28 : $132-5$.

4. Costa NA, Marinho AD, Cançado LR. Nutritional requirements of the critically ill patient. Rev Bras Ter Intensiva 2012; 24: 270-277.

5. Cruz CM, Silva, AFD, Anjos LA. A taxa metabólica basal é superestimada pelas equações preditivas em universitárias do Rio de Janeiro, Brasil. Arch Latinoam Nutr 1999; 49: 232-237.

6. De Lorenzo A, Bertini I, Puijia A, Testolin G, Testolin C. Comparison between measured and predicted resting metabolic rate in moderately active adolescents. Acta Diabetologica 1999; 36: 141-145

7. Dutra LN, Damasceno VO, Silva AC, Vianna JM, Junior JMN, Lima JRP. Estimativa do gasto energético da caminhada. Rev Bras Med Esporte 2007; 13: 321-326.

8. Ferreira LG, Santos LF, Silva TRN, Anastácio LR, Lima AS, Correia MITD Hyper- and hypometabolism are not related to nutritional status of patients on the waiting list for liver transplantation. Clin Nutr 2013; 1-7.

9. Fett CA, Fett WCR, Marchini JS. Gasto Energético de Repouso Medido Vs. Estimado e Relação com a Composição Corporal de Mulheres. Arq Bras Endocrinol Metabol 2006; 50: 1050-1058.

10. Gottschall CB, Alvares-da-Silva MR, Camargo AC, Burtett RM, da Silveira TR. Nutritional assessment in patients with cirrhosis: the use of indirect calorimetry. Arq Gastroenterol. 2004; 41: 220-224.

11. Hanouneh IA, Feldstein AE, McCullough AJ, Miller C, Aucejo F, Yerian $\mathrm{L}$, Lopez $\mathrm{R}$, et al. The significance of metabolic syndrome in the setting of recurrent hepatitis C after liver transplantation. Liver Transpl. 2008; 14: 1287-1293.

12. Kyle UG, Bosaeusb I, Lorenzoc ADD, Deurenbergd P, Eliae M, G!omezf JM, Heitmanng BL, et al. Composition of the ESPEN Working Group. Bioelectrical impedance analysis part I: review of principles and methods. Clin Nutr 2004; 23:1226-1243.

13. Marinho A, Pinho J, Cançado LR, Oliveira MM, Oliveira MG, Marinho R, Martins FR. Avaliação das necessidades energéticas no doente crítico. Revista APNEP 2012; 6: 19 -24.

14. Mifflin MD, St Jeor ST, Hill LA, Scott BJ, Daugherty SA, Koh YO. A new predictive equation for resting energy expenditure in healthy individuals. Am J Clin Nutr 1990; 51: 241-7.

15. Nhung BT, Khan NC, Hop LT, Lam NT, Khanh NLB, Lien DTK, Nakamor $\mathrm{M}$, et al. Resting Metabolic Rate of Elderly Vietnamese. J Nutr Met Dis and Dietetics 2007; 51: 7-13.

16. ParolinMB,ZainaFE, Lopes RW. Nutritionaltherapyinlivertransplantation. Arq Gastroenterol 2002; 39: 114-122.

17. Pereira MP, Rocha GT, Santos LGM, Viana GCG, Navarro AC. Avaliação das equações de predição da taxa metabólica basal em homens e mulheres ativos residentes em Brasília, DF, Brasil. Revista Brasileira de Nutrição Esportiva 2008; 2: 67-75.

18. Richardson RA, GardenOJ, Davidson HI. Reduction inenergyexpenditure after liver transplantation. Nutrition 2001; 17:585-589.

19. Schneider $P$, Meyer F. As equações de predição da taxa metabólica basal são apropriadas para adolescentes com sobrepeso e obesidade? Rev Bras Med Esporte 2005; 11: 193-196.

20. Segal KR, Gutin B, Presta E, Wang J, van Itallie TB. Estimation of human body composition by electrical impedance methods a comparative study. J Appl Physiol 1985; 58: 1565-1571.

21. TversKaya R, Rising R, BrownD, LifshitzF.Comparison ofSeveral Equations and Derivation of a New Equation for Calculating Basal Metabolic Rate in Obese Children. J Am Coll Nutr 1998; 17: 333-336.

22. Wahrlich V,Anjos LA. Validation of predictiveequations ofbasalmetabolic rate ofwomen living in Southern Brazil. RevSaude Pública2001;35:39-45. 